\title{
SOME PLANTS OF OUR DUNELANDS
}

\section{by Keith F. Best and Arch. C. Budd}

In the southwest of our province is a large area of sanid and sand dunes, the Great Sandhills and their smaller neighbouring dune lands. These have their own peculiar vegetation, and a number of plants are found there that apparently will not thrive except on these sandy soils.

In the June issue, we dealt with four native grasses whose presence indicate sandy soil. Now let's take a look at two legume species that are generally associated with our sand dunes.

One of the first species to commence the re-vegetation of a shifting sand dune is the Lance-leaved Psonalea (Psoralea lanceolata). This close relative of the Indian Breadroot is a low growing plant of a yellowish-green colour with yards and yards of tough, cord-like rootstocks, branching in every direction. The finely glandular leaves have three, occasionally five, linear lanceolate leaflets from $1 / 2$ to $1 \frac{1}{2}$ inches lang. The bluish-white flowers are
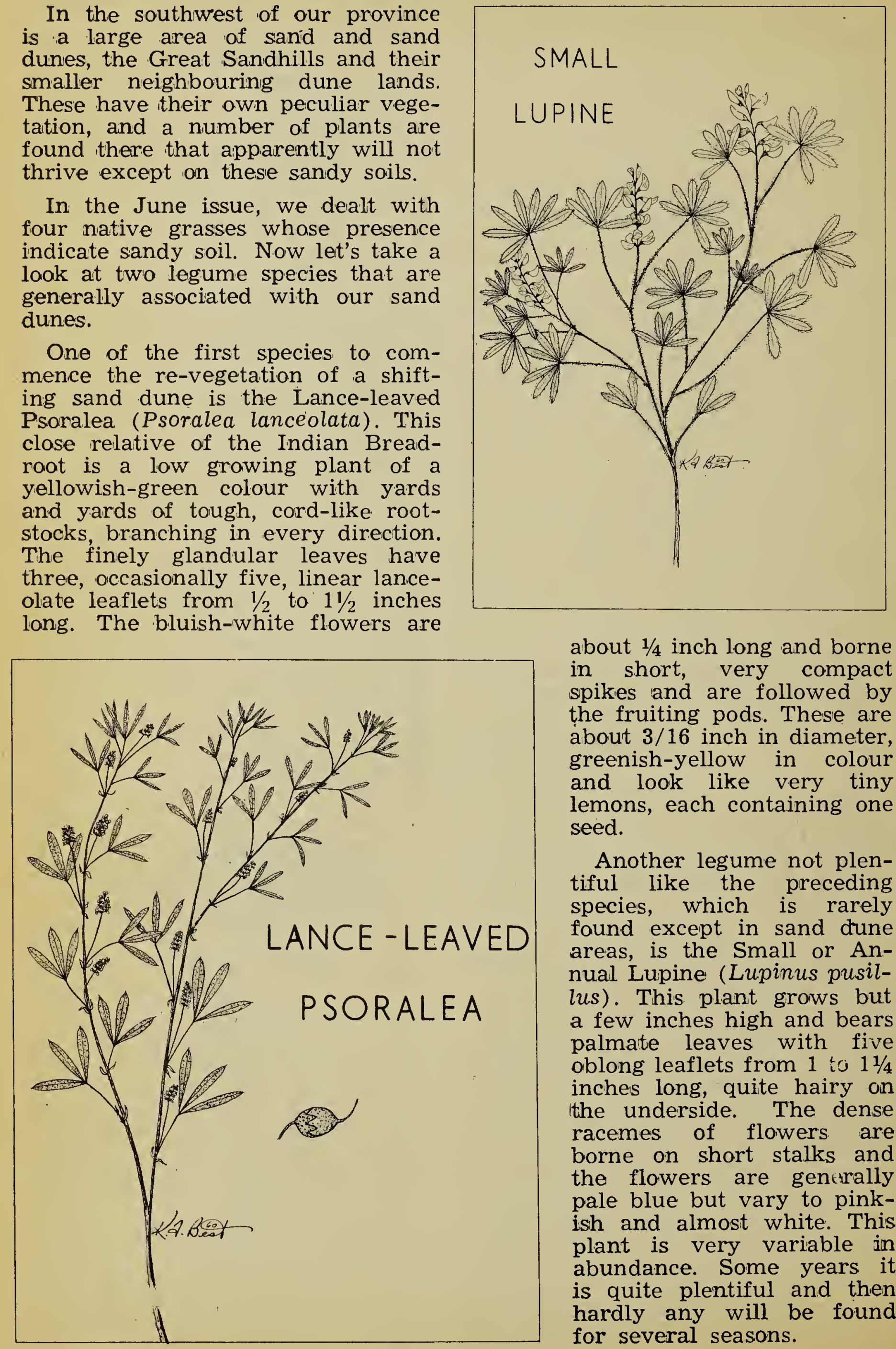

about $1 / 4$ inch long and borne in short, very compact spikes and are followed by the fruiting pods. These are about 3/16 inch in diameter, greenish-yellow in colour and look like very tiny lemons, each containing one seed.

Another legume not plentiful like the preceding species, which is rarely found except in sand dune areas, is the Small or Annual Lupine (Lupinus pusillus). This plant grows but a few inches high and bears palmate leaves with five oblong leaflets from 1 to $1 \frac{1}{4}$ inches long, quite hairy on the underside. The dense racemes of flowers are borne on short stalks and the flowers are genurally pale blue but vary to pinkish and almost white. This plant is very variable in abundance. Some years it is quite plentiful and then hardly any will be found for several seasons. 


\section{SYRINGA OR MOCK ORANGE} Philadelphus lewisii Pursh

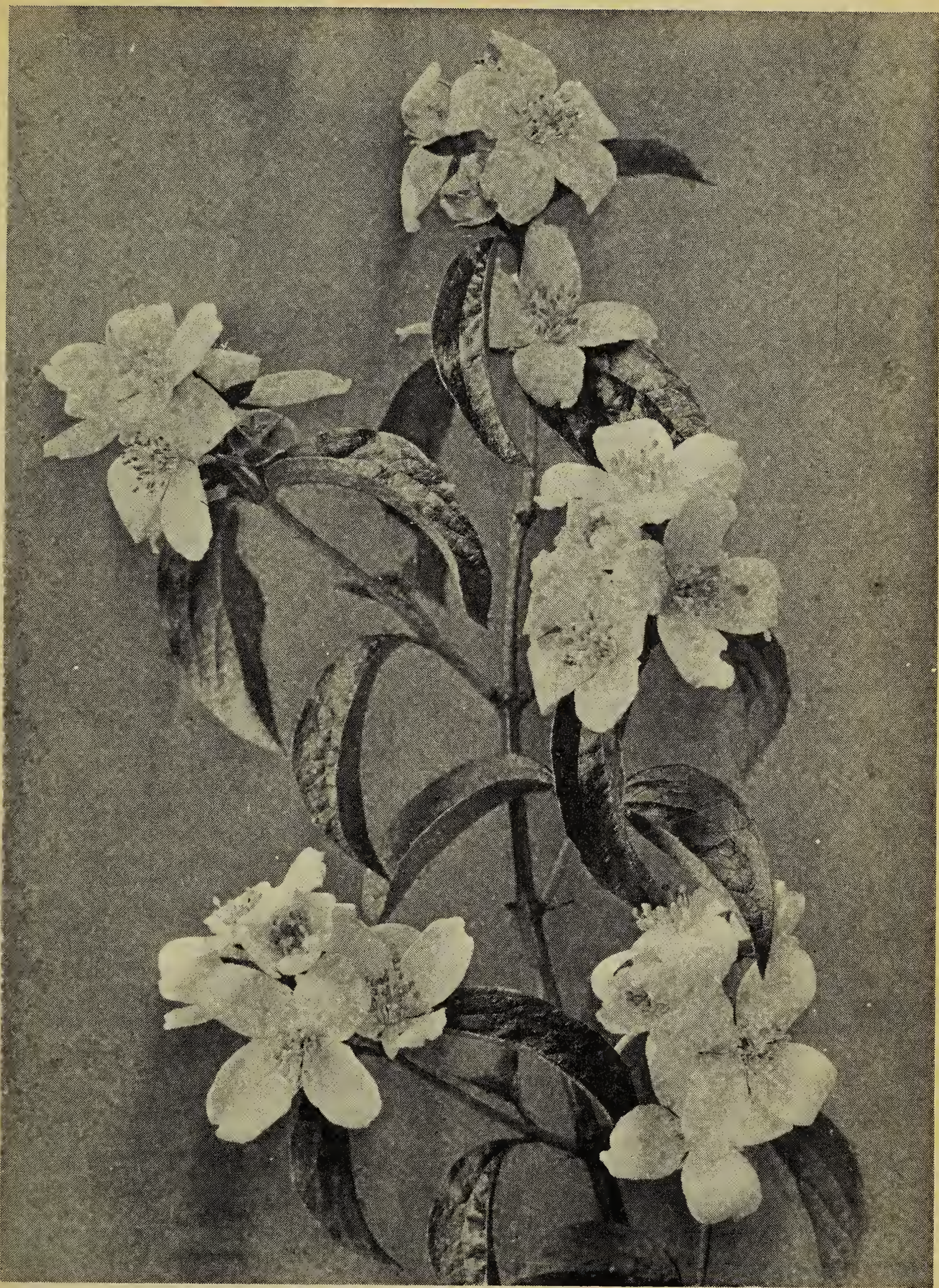

Photo by W. C. McCalla

The Syringa on Mock Orange is a shrub four to eight feet high with snowy white, fragrant flowers. It is abundant in B.C. and at Waterton, and has been planted and does well at Calgary and Edmonton. Prairie nurseries warn that it is not dependably hardy throughout the rest of the prairies, and that it sometimes tip kills. However, I have had a beauitful mass of Mock Orange bloom this summer at 2335 Athol St., Regina. If you have a very shelitered location you may like to experiment with Mock Orange.-Ed. 